\title{
Gonadotrophin response to LH-RH in boys with delayed growth and adolescence
}

\author{
M O SAVAGe, M A PREeCE, N CAMERON, J JONES, G THEINTZ, J L PENFOLD, \\ AND J M TANNER
}

Department of Growth and Development, and Department of Chemical Pathology, Institute of Child Health, and The Hospital for Sick Children, London

SUMMARY Plasma luteinising hormone (LH) and follicle-stimulating hormone (FSH) concentrations were measured before and after intravenous luteinising hormone-releasing hormone (LH-RH) in 33 boys with growth delay. Eighteen were prepubertal and 15 pubertal. Basal LH and FSH levels were low in both groups with mean increments after LH-RH of $3.2 \pm 0.8 \mathrm{U} / \mathrm{l}$ (mean \pm SEM) and $2.6 \pm 0.4$ $\mathrm{U} / 1$ respectively in the prepubertal and $7 \cdot 4 \pm 0.7 \mathrm{U} / 1$ and $2 \cdot 0 \pm 0.3 \mathrm{U} / 1$ in the pubertal boys. The LH increment showed a positive correlation with increasing bone age $(r=0.71, \mathrm{P}<0.001)$; FSH did not. The LH-RH response thus appeared normal in relation to the stage of maturity.

Growth delay is the most common cause of short stature. Despite the good prognosis in terms of final stature and pubertal development, a delay in growth and puberty, which generally coexist, can be a source of considerable unhappiness in the affected child. Boys appear to be more often affected than girls ${ }^{12}$ but it is not absolutely clear how much of this sexual difference is due to varying social pressures; short stature seems to lead to greater anxiety in boys.

Pituitary secretion of the gonadotrophins luteinising hormone (LH) and follicle-stimulating hormone (FSH) increases during normal male puberty ${ }^{3}{ }^{4}$ as the sensitivity of the hypothalamus to the negative feed-back effect of sex steroids diminishes, ${ }^{5}$ or possibly due to release of inhibition by the pineal gland. ${ }^{6}$ In the prepubertal child however, basal plasma LH and FSH levels are low and are of little prognostic value in the investigation of the patient with delayed puberty. The isolation and synthesis of the hypothalamic luteinising hormone-releasing hormone (LH-RH) ${ }^{7}$ has provided a potential means of assessing pituitary gonadotrophin release before the appearance of clinical signs of puberty. ${ }^{8}$ The LH-RH test has become established as a method of demonstrating pituitary gonadotrophin reserve $\mathrm{e}^{\mathbf{1 0}}$ and it was hoped that it would distinguish between children with simple pubertal delay and those with hypopituitarism. However, the value of the LH-RH test in this respect has not been conclusively demonstrated, partly because of variability of individual responses and partly because of uncertainty of the relationship between the magnitude of the response and pubertal maturation.

The aim of the present study was to measure plasma LH and FSH responses to intravenous administration of LH-RH in prepubertal and pubertal boys with delay of growth and puberty, and to relate these findings to skeletal maturation and clinical pubertal development of the subjects.

\section{Patients}

Thirty-three boys were studied; they had been referred either because of short stature or delayed puberty. Eighteen were prepubertal (Table 1) and 15 pubertal (Table 2). The distinction between the prepubertal and pubertal subjects was made according to testicular volume. Subjects with a mean testicular volume $<4 \mathrm{ml}$ were classified as prepubertal, and those with $4 \mathrm{ml}$ or greater were classified as pubertal. The mean age of the prepubertal group was $12 \cdot 1$ (range $9 \cdot 8-14 \cdot 8$ ) years and that of the pubertal group $15 \cdot 1$ (range 12.6-16.4) years. No boy was growth hormone or thyrotrophin deficient.

\section{Methods}

All the patients underwent measurements of stature and other anthropometric variables by the same observer (NC) according to Cameron. ${ }^{11}$ Genitalia and pubic hair stages were assessed by one of us (MOS, MAP, or JMT) using the criteria of 
Table 1 Clinical and hormonal data for the 18 prepubertal boys

\begin{tabular}{|c|c|c|c|c|c|c|}
\hline \multirow[t]{3}{*}{ Cases } & \multirow{3}{*}{$\begin{array}{l}\text { Chrono- } \\
\text { logical } \\
\text { age (years) }\end{array}$} & \multirow{3}{*}{$\begin{array}{l}\text { Bone } \\
\text { age } \\
\text { ('years') }\end{array}$} & \multicolumn{4}{|c|}{$L H-R H$ test } \\
\hline & & & \multicolumn{2}{|c|}{$\begin{array}{l}\text { Plasma LH } \\
(I U / l)\end{array}$} & \multicolumn{2}{|c|}{$\begin{array}{l}\text { Plasma FSH } \\
(I U / l)\end{array}$} \\
\hline & & & Basal & Peak & Basal & Peak \\
\hline $\begin{array}{r}1 \\
2 \\
3 \\
4 \\
5 \\
6 \\
7 \\
8 \\
9 \\
10 \\
11 \\
12 \\
13 \\
14 \\
15 \\
16 \\
17 \\
18\end{array}$ & $\begin{array}{r}11 \cdot 4 \\
9 \cdot 8 \\
9 \cdot 9 \\
14 \cdot 1 \\
13 \cdot 0 \\
13 \cdot 3 \\
11 \cdot 3 \\
10 \cdot 2 \\
9.9 \\
11 \cdot 6 \\
12 \cdot 2 \\
11 \cdot 3 \\
13 \cdot 2 \\
13 \cdot 8 \\
10 \cdot 2 \\
14 \cdot 1 \\
14 \cdot 2 \\
14 \cdot 8\end{array}$ & $\begin{array}{r}10.6 \\
8.6 \\
8 \cdot 1 \\
12 \cdot 2 \\
10 \cdot 5 \\
10 \cdot 1 \\
8 \cdot 8 \\
8 \cdot 0 \\
8 \cdot 1 \\
7.9 \\
10.0 \\
9.4 \\
11 \cdot 4 \\
9.5 \\
8 \cdot 0 \\
12.4 \\
13.4 \\
11.4\end{array}$ & $\begin{array}{l}0.5 \\
1.4 \\
1.2 \\
0.5 \\
3.0 \\
0.5 \\
0.5 \\
0.5 \\
1.0 \\
0.5 \\
0.5 \\
0.5 \\
0.5 \\
0.5 \\
2.0 \\
1.0 \\
0.5 \\
1.0\end{array}$ & $\begin{array}{r}0 \cdot 5 \\
7 \cdot 0 \\
1 \cdot 2 \\
2 \cdot 2 \\
7 \cdot 0 \\
7 \cdot 2 \\
2 \cdot 0 \\
1 \cdot 0 \\
3 \cdot 0 \\
0 \cdot 5 \\
4 \cdot 0 \\
0 \cdot 5 \\
2 \cdot 5 \\
0 \cdot 5 \\
4 \cdot 5 \\
10 \cdot 0 \\
12 \cdot 2 \\
8 \cdot 3\end{array}$ & $\begin{array}{l}1 \cdot 2 \\
1 \cdot 2 \\
2.0 \\
0.5 \\
1.4 \\
1 \cdot 3 \\
2.6 \\
1.0 \\
2.0 \\
0.5 \\
0.5 \\
1.9 \\
0.5 \\
0.5 \\
1.0 \\
1.5 \\
1.9 \\
4 \cdot 2\end{array}$ & $\begin{array}{r}6 \cdot 7 \\
4 \cdot 4 \\
4 \cdot 5 \\
4 \cdot 0 \\
4 \cdot 4 \\
5 \cdot 0 \\
2 \cdot 9 \\
3 \cdot 8 \\
3 \cdot 7 \\
3 \cdot 0 \\
2 \cdot 1 \\
3 \cdot 5 \\
1 \cdot 7 \\
1 \cdot 9 \\
1 \cdot 9 \\
3 \cdot 2 \\
4 \cdot 5 \\
11 \cdot 5\end{array}$ \\
\hline $\begin{array}{l}\text { Mean } \\
\text { Range }\end{array}$ & $\begin{array}{l}12 \cdot 1 \\
9 \cdot 8-14 \cdot 8\end{array}$ & $\begin{array}{l}9 \cdot 9 \\
8 \cdot 0-13 \cdot 4\end{array}$ & $\begin{array}{l}0.9 \\
0.5-3.0\end{array}$ & $\begin{array}{l}4 \cdot 1 \\
0 \cdot 5-12 \cdot 2\end{array}$ & $\begin{array}{l}1 \cdot 3 \\
0.5-2 \cdot 6\end{array}$ & $\begin{array}{l}4 \cdot 0 \\
1 \cdot 7-11 \cdot 5\end{array}$ \\
\hline
\end{tabular}

Tanner ${ }^{12}$ and testicular volume was measured using an orchidometer. ${ }^{13}$ Bone age was assessed in all boys by the same observer (NC) using the TW2-RUS method.14

The LH-RH test was performed after an overnight fast using $0.1 \mathrm{mg}$ of LH-RH (Ayerst) administered intravenously as a bolus. In 20 boys the LH-RH was given simultaneously with thyrotrophin-releasing hormone (TRH) $0.2 \mathrm{mg}$ and insulin 0.1 units $/ \mathrm{kg}$ as part of a more general investigation of pituitary function. Venous blood samples were taken for measurement of LH and FSH at 0 minutes, and at 20 and 60 minutes after the injection of LH-RH. Serum samples were stored at $-20^{\circ} \mathrm{C}$ before assay.

Methodology of LH and FSH assays. Serum LH and FSH were measured by double antibody radioimmunoassay in duplicate. Results were expressed in IU/l of the MRC pituitary standards $68 / 40$ for $\mathrm{LH}$ and 69/104 for FSH.

Anti-LH (14673) and anti-FSH M93 (6873) were donated by Professor Wilfred Butt. Radioiodination was performed by the chloramine $T$ method of Hunter and Greenwood ${ }^{15}$ using material for iodination also donated by Professor Butt. Donkey antirabbit precipitating serum was supplied by Wellcome Reagents Ltd. Interassay coefficient of variation in the methods used was 5 to $12 \%$.

\section{Results}

Auxological features. The mean height standard deviation score (SDS) of the prepubertal boys was $-3 \cdot 2$ (range $-2 \cdot 0$ to $-4 \cdot 8$ ), that of the pubertal boys -2.9 (range -1.4 to $-4 \cdot 6$ ). The mean bone age of the prepubertal boys was 9.9 'years' (range 8.0 to 13.4 ), that of the pubertal ones 12.8 'years' (range 11.3 to 14.6 ). Mean testicular volume was $<4 \mathrm{ml}$ in all the prepubertal boys, and ranged from 4 to $8 \mathrm{ml}$ in the pubertal ones.

All the boys were re-examined clinically 6 months after the LH-RH test. All 15 pubertal subjects had continued normal pubertal development. Five of the 18 prepubertal boys had started puberty, but there

Table 2 Clinical and hormonal data for the 15 pubertal boys

\begin{tabular}{|c|c|c|c|c|c|c|c|c|c|}
\hline \multirow[t]{3}{*}{ Cases } & \multirow{3}{*}{$\begin{array}{l}\text { Chronological } \\
\text { age (years) }\end{array}$} & \multirow{3}{*}{$\begin{array}{l}\text { Bone age } \\
\text { ('years') }\end{array}$} & \multirow{3}{*}{$\begin{array}{l}\text { Genitalia } \\
\text { rating }\end{array}$} & \multirow{3}{*}{$\begin{array}{l}\text { Pubic hair } \\
\text { rating }\end{array}$} & \multirow{3}{*}{$\begin{array}{l}M T V \\
(m l)\end{array}$} & \multicolumn{4}{|c|}{$L H-R H$ test } \\
\hline & & & & & & \multicolumn{2}{|c|}{ Plasma LH $(I U / l)$} & \multicolumn{2}{|c|}{ Plasma FSH $(I U / l)$} \\
\hline & & & & & & Basal & Peak & Basal & Pea'c \\
\hline $\begin{array}{r}1 \\
2 \\
3 \\
4 \\
5 \\
6 \\
7 \\
8 \\
9 \\
10 \\
11 \\
12 \\
13 \\
14 \\
15\end{array}$ & $\begin{array}{l}15 \cdot 3 \\
16 \cdot 4 \\
15 \cdot 3 \\
15 \cdot 9 \\
14 \cdot 2 \\
15 \cdot 5 \\
14 \cdot 3 \\
12 \cdot 6 \\
15 \cdot 2 \\
14 \cdot 6 \\
14 \cdot 9 \\
15 \cdot 8 \\
13 \cdot 8 \\
16 \cdot 4 \\
15 \cdot 8\end{array}$ & $\begin{array}{l}11 \cdot 4 \\
12 \cdot 7 \\
14 \cdot 1 \\
13 \cdot 5 \\
12 \cdot 5 \\
14 \cdot 0 \\
11 \cdot 5 \\
11 \cdot 3 \\
12 \cdot 8 \\
12 \cdot 2 \\
11 \cdot 8 \\
14 \cdot 6 \\
12 \cdot 4 \\
14 \cdot 2 \\
12 \cdot 5\end{array}$ & $\begin{array}{l}1 \\
2 \\
1 \\
2 \\
2 \\
1 \\
2 \\
2 \\
2 \\
2 \\
2 \\
2 \\
1 \\
2 \\
2\end{array}$ & $\begin{array}{l}1 \\
2 \\
1 \\
3 \\
2 \\
2 \\
1 \\
1 \\
2 \\
2 \\
1 \\
1 \\
2 \\
3 \\
1\end{array}$ & $\begin{array}{l}5 \\
8 \\
5 \\
6 \\
8 \\
4 \\
4 \\
5 \\
4 \\
4 \\
5 \\
6 \\
4 \\
8 \\
5\end{array}$ & $\begin{array}{l}3.5 \\
0.5 \\
0.5 \\
0.5 \\
0.5 \\
1.8 \\
0.5 \\
0.5 \\
1.0 \\
1.0 \\
1.0 \\
0.5 \\
0.5 \\
1.0 \\
1.0\end{array}$ & $\begin{array}{r}14 \cdot 0 \\
3 \cdot 5 \\
11 \cdot 5 \\
8 \cdot 2 \\
10 \cdot 0 \\
6 \cdot 1 \\
6 \cdot 0 \\
3 \cdot 5 \\
8 \cdot 3 \\
9 \cdot 2 \\
7 \cdot 3 \\
8.0 \\
5 \cdot 9 \\
13.0 \\
9.9\end{array}$ & $\begin{array}{l}1 \cdot 0 \\
1 \cdot 2 \\
1 \cdot 5 \\
0.5 \\
2 \cdot 0 \\
2 \cdot 0 \\
0.5 \\
2 \cdot 1 \\
1 \cdot 7 \\
1 \cdot 6 \\
1 \cdot 0 \\
1 \cdot 2 \\
1.0 \\
2.5 \\
4 \cdot 0\end{array}$ & $\begin{array}{l}3.0 \\
3.0 \\
3.0 \\
1.5 \\
7.0 \\
4 \cdot 0 \\
4 \cdot 2 \\
4 \cdot 9 \\
2.0 \\
4.0 \\
2.5 \\
2.8 \\
2.3 \\
6.3 \\
4.0\end{array}$ \\
\hline $\begin{array}{l}\text { Mean } \\
\text { Range }\end{array}$ & $\begin{array}{l}15 \cdot 1 \\
12 \cdot 6-16 \cdot 4\end{array}$ & $\begin{array}{l}12 \cdot 8 \\
11 \cdot 3-14 \cdot 6\end{array}$ & $1-2$ & 1-3 & $4-8$ & $\begin{array}{l}0.9 \\
0.5-3.5\end{array}$ & $\begin{array}{l}8 \cdot 3 \\
3 \cdot 5-14 \cdot 0\end{array}$ & $\begin{array}{l}1 \cdot 2 \\
0 \cdot 5-4 \cdot 0\end{array}$ & $\begin{array}{l}3 \cdot 6 \\
1 \cdot 5-7 \cdot 0\end{array}$ \\
\hline
\end{tabular}

MTV = mean testicular volume. 
was no correlation between the timing of the onset of puberty and the amplitude of the LH and FSH response to LH-RH.

\section{LH and FSH concentrations (Tables 1 and 2)}

\section{Luteinising hormone}

Basal plasma LH concentrations were similar in the prepubertal (mean 0.9 IU/1 (range 0.5-3.0) ) and pubertal boys (mean $0.9 \mathrm{lU} / \mathrm{l}$ (range $0.5-3.5$ )) Plasma LH increased significantly after LH-RH with a mean maximum increment in the prepubertal boys of $3 \cdot 2 \mathrm{IU} / 1$ (range $0-9 \cdot 0, \mathrm{P}<0 \cdot 001$ ) and in the pubertal boys of $7 \cdot 4 \mathrm{IU} / \mathrm{l}$ (range $3 \cdot 0-12 \cdot 0$, $\mathrm{P}<0.001$ ). The mean maximum increment was significantly greater in the pubertal than in the prepubertal boys $(\mathrm{P}<0 \cdot 001)$. There was wide variation of individual LH responses to LH-RH in the prepubertal subjects (Fig. 2). In 5 boys there was no response.

\section{Follicle-stimulating hormone}

Basal plasma FSH concentrations were similar in the prepubertal (mean 1.3 IU/l (range 0.5-2.6) ) and the pubertal boys (mean $1 \cdot 2 \mathrm{IU} / 1$ (range $0 \cdot 5-4 \cdot 2)$ ).

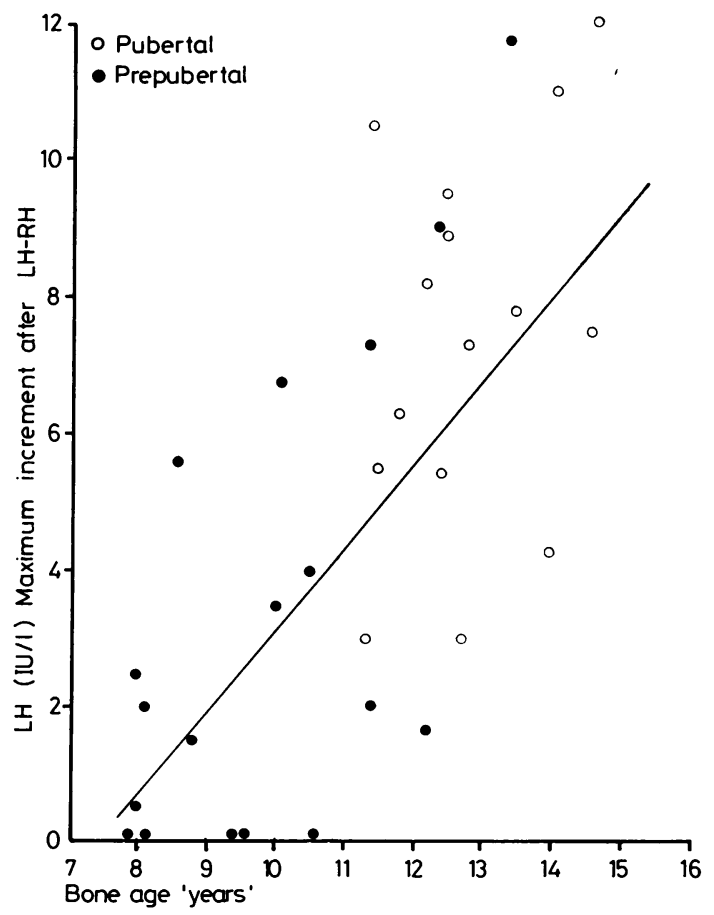

Fig. 1 Maximum increment of plasma $\mathrm{LH}$ after $L H-R H$ plotted against bone age $(r=0.71, P<0.001)$.

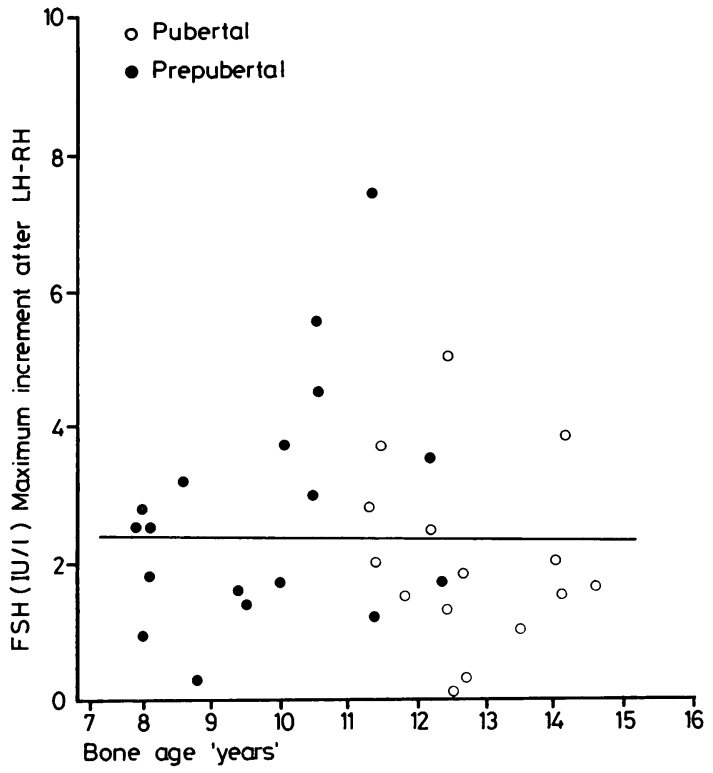

Fig. 2 Maximum increment of plasma FSH after LH-RH plotted against bone age $(r=-0.01, P>0 \cdot 1)$.

Plasma FSH increased significantly after LH-RH with a mean maximum increment in the prepubertal boys of $2.6 \mathrm{IU} / 1$ (range $0.3-4.5, \mathrm{P}<0.001$ ) and in the pubertal boys of $2 \cdot 0$ IU/l (range $0-5 \cdot 0$, $P<0.001$ ). Unlike LH, there was no difference in the mean FSH increments after LH-RH between the prepubertal and the pubertal boys.

Correlation of LH and FSH with bone age. There was no correlation between basal concentrations of $\mathrm{LH}$ and FSH with advancing bone age. The LH increment after LH-RH however, showed a positive correlation with increasing bone age (Fig. 1) $(\mathrm{r}=0.71, \mathrm{P}<0.001)$. The FSH increment showed no such correlation $(\mathrm{r}=-0 \cdot 01, \mathrm{P}<0 \cdot 1)$ (Fig. 2$)$.

\section{Discussion}

The plasma $\mathrm{LH}$ and FSH responses to intravenous administration of LH-RH confirm that releasable stores of these gonadotrophins are present in at least some prepubertal and all pubertal boys. ${ }^{16} 17$ As previously reported, the patterns of $\mathrm{LH}$ and FSH responses were different. The amplitude of the LH response was consistently greater ${ }^{9}$ than that of FSH, and the $\mathrm{LH}$ response in pubertal boys was significantly greater than in prepubertal ones, ${ }^{18}$ there being no difference in the FSH responses. ${ }^{10}$

The wide variation of individual responses to LH-RH previously reported ${ }^{18}$ was found in the 
present study too, and clearly contributes to the difficulty in interpreting the results of this test in the individual patient. Kelch et al. ${ }^{19}$ studied the relationship of LH and FSH responses to skeletal maturation in normal boys and found that $\mathrm{LH}$ responsiveness increased greatly after a bone age of 10 years, whereas the FSH response showed no clear bone age dependency. In the present study the positive correlation of the maximum increment of $\mathrm{LH}$, but not FSH, with increasing bone age agrees with this finding. The linear relationship between releasable stores of $\mathrm{LH}$ and increasing bone age may be explained by the known effect of testosterone production, for which LH is the principal stimulus, on skeletal maturation. Burr et al. ${ }^{20}$ reported no increase of basal plasma LH in subjects with early testicular enlargement compared with those with prepubertal testes, although an increase in FSH was noted. In the present study basal LH and FSH remained within the prepubertal range. However, none of the subjects had a mean testicular volume $>8 \mathrm{ml}$, indicating that these hormonal findings represent a narrow cross-section of pubertal development.

The stage of skeletal maturation (bone age 11-12 'years') which coincided with the transition between boys with prepubertal testicular volume and those with early testicular enlargement is consistent with the findings of Burr et al. ${ }^{20}$ and August et al. ${ }^{21}$

The LH-RH test has become an established method of demonstrating impaired production of gonadotrophins in children with hypopituitarism. ${ }^{16} 22$ However the variability of response in the prepubertal subject with both pituitary ${ }^{22}$ or hypothalamic ${ }^{23}$ dysfunction suggests that no clear distinction can be made on the basis of the LH-RH test between subjects with these disorders and those with simple delayed puberty. Job et al. ${ }^{16}$ reported that gonadotrophin response overlapped in these three disorders. The present study has confirmed the variability of individual responses, particularly of $\mathrm{LH}$, in boys with delayed puberty ${ }^{24}$ and has demonstrated that a consistent increment of LH only occurred in the boys with a bone age of greater than 11 'years'. In $7(39 \%)$ of 18 prepubertal boys the increment was at least $3.5 \mathrm{IU} / \mathrm{l}$. This response was higher than the lower limit of the response of the pubertal subjects (3.0 IU/l) who proceeded to normal pubertal development. Consequently, a prepubertal response of this magnitude probably excludes gonadotrophin deficiency and suggests that these subjects will develop normally. A longitudinal study will be necessary to confirm this hypothesis.

The LH-RH test may thus contribute to the investigation of boys with delayed puberty provided the gonadotrophin response is evaluated in the context of skeletal maturation. A consistent LH response appears to be more likely in subjects with a bone age greater than 11 'years'.

We thank Dr D B Grant for permission to publish data on his patients.

G $\mathbf{T}$ was a Swiss National Science Foundation Research Fellow.

\section{References}

1 Prader A. Constitutional delay of growth and puberty. In: Chiumello G, Laron Z, eds. Recent progress in paediatric endocrinology. London: Academic Press, 1977: 129-38.

2 Preece M A. Growth delay. Acta Paediatr Belgica 1979; 32: 7-15.

3 Faiman C, Winter J S D. Gonadotrophins and sex hormone patterns in puberty: clinical data. In: Grumbach M M, Grave G D, Mayer F E, eds. Control of the onset of puberty. New York: Wiley, 1974: 32-55.

4 Sizonenko P C. Endocrinology in preadolescents and adolescents. Am J Dis Child 1978; 132: 704-12.

5 Kulin H E, Grumbach M M, Kaplan S L. Gonadalhypothalamic interaction in prepubertal and pubertal man: effect of clomiphene citrate on urinary folliclestimulating hormone and luteinizing hormone and plasma testosterone. Pediatr Res 1972; 6: 162-71.

6 Silman R E, Leone R M, Hooper R J L, Preece M A. Melatonin, the pineal gland, and human puberty. Nature 1979; 282: 301-3.

7 Schally A V, Arimura A, Kastin A J, et al. Gonadotropinreleasing hormone: one polypeptide regulates secretion of luteinizing and follicle-stimulating hormones. Science 1971; 173: 1036-8.

8 Grumbach M M, Roth J C, Kaplan S L, Kelch R P. Hypothalamic-pituitary regulation of puberty in man. Evidence and concepts derived from clinical research. In: Grumbach M M, Grave G D, Mayer F E, eds. Control of the onset of puberty. New York: Wiley, 1974: 115-66.

9 Job J C, Garnier P E, Chaussain J L, Milhaud G. Elevation of serum gonadotropins ( $\mathrm{LH}$ and $\mathrm{FSH}$ ) after releasing hormone (LH-RH) injection in normal children and in patients with disorders of puberty. $J$ Clin Endocrinol Metab 1972; 35 : 473-6.

10 Roth J C, Grumbach M M, Kaplan S L. Effect of synthetic luteinizing hormone-releasing factor on serum testosterone and gonadotropins in prepubertal, pubertal, and adult males. J Clin Endocrinol Metab 1973; 37: 680-5.

11 Cameron N. The methods of auxological anthropometry. In: Falkner F, Tanner J M, eds. Human growth. New York: Plenum, 1978: 35-87.

12 Tanner J M. The development of the reproductive system. In: Growth at adolescence, second edition. Oxford: Blackwell, 1962: 28-39.

13 Zachmann M, Prader A, Kind H P, Häfliger H, Budliger $H$. Testicular volume during adolescence. Cross-sectional and longitudinal studies. Helv Paediatr Acta 1974; 29: 61-72.

14 Tanner J M, Whitehouse R H, Marshall W A, Healy M J R, Goldstein $\mathrm{H}$. Assessment of skeletal maturity and prediction of adult height (TW2 method). London: Academic Press, 1975.

15 Hunter W M, Greenwood F C. Preparation of iodine-131 labelled human growth hormone of high specific activity. Nature 1962; 194: 495-6. 
16 Job J C, Chaussain J L, Garnier P E. The use of luteinizing hormone-releasing hormone in paediatric patients. Horm Res 1977; 8: 171-87.

17 Franchimont P, Becker H, Ernould C, et al. The effect of hypothalamic luteinizing hormone releasing hormone (LH-RH) on plasma gonadotrophin levels in normal subjects. Clin Endocrinol 1974; 3: 27-39.

18 Dickerman Z, Prager-Lewin R, Laron Z. Response of plasma LH and FSH to synthetic LH-RH in children at various pubertal stages. Am J Dis Child 1976; 130: 634-8.

19 Kelch R P, Markovs M, Huss J. LH and FSH responsiveness to intravenous gonadotropin-releasing hormone (GnRH) in children with hypothalamic or pituitary disorders: lack of effect of replacement therapy with human growth hormone. J Clin Endocrinol Metab 1976; 42: 1104-13.

20 Burr I M, Sizonenko P C, Kaplan S L, Grumbach M M. Hormonal changes in puberty. I. Correlation of serum luteinizing hormone and follicle-stimulating hormone with stages of puberty, testicular size, and bone age in normal boys. Pediatr Res 1970; 4: 25-35.

21 August G P, Grumbach M M, Kaplan S L. Hormonal changes in puberty. III. Correlation of plasma testosterone
LH, FSH, testicular size, and bone age with male pubertal development. J Clin Endocrinol Metab 1972; 34: 319-26. 22 Chaussain J L, Garnier P E, Binet E, Vassal J, Scholler R, Job J C. Effect of synthetic luteinizing hormone-releasing hormone (LH-RH) on the release of gonadotropins in hypophysogonadal disorders of children and adolescents. III. Hypopituitarism. J Clin Endocrinol Metab 1974; 38: 58-63.

23 Bell J, Spitz I, Slonim A, et al. Heterogeneity of gonadotropin response to LH-RH in hypogonadotropic hypogonadism. J Clin Endocrinol Metab 1973; 36: 791-4.

24 Job J C, Chaussain J L, Garnier P E, Toublanc J E. Effect of synthetic luteinizing hormone-releasing hormone on the release of gonadotropins in hypophysogonadal disorders of children and adolescents. VII. Constitutional delay of puberty in males. $J$ Pediatr $1976 ; 88$ : 494-8.

Correspondence to Dr M O Savage, Department of Endocrinology, The Hospital for Sick Children, Gt Ormond Street, London WC1N 3JH.

Received 15 April 1980

The following articles will appear in future issues of this journal:

Prevention of infective endocarditis $O$ Scott

Sickle cell haemoglobinopathies in England $J R$ Mann

Vitamin status in treated patients with cystic fibrosis

P J Congden, G Bruce, M M Rothburn, P C N Clarke, J M Littlewood, J Kelleher, and M S Losowsky

Fetal lung hypoplasia: biochemical and structural variations and their possible significance $J$ W Wigglesworth, $R$ Desai, and P Guerrini

Covert bacteriuria in schoolgirls in Newcastle upon Tyne: a 5-year follow-up

Newcastle Covert Bacteriuria Research Group

Effect of vesicoureteric reflux on renal growth in children with urinary tract infection $J M$ Smellie, D Edwards, I C S Normand, and N Prescod

Toddler diarrhoea and prostaglandins $J$ A Dodge, I A Hamdi, G M Burns, and Y Yamashiro 